p-ISSN: $2338-4794$

e-ISSN: $2579-7476$

Vol.8. No. 1 Januari-April 2020

\title{
PENGARUH KOMPETENSI DAN LINGKUNGAN KERJA TERHADAP KINERJA KARYAWAN PT. HEXINDO ADIPERKASA
}

\author{
Kartika Dwi Astuti ${ }^{1}$ ) \\ 1) Mahasiswa Program Studi Manajemen FE UNKRIS \\ Amanda Setiorini ${ }^{2)}$ \\ 2) Dosen Program Studi Manajemen FE UNKRIS \\ Alamat: Kampus UNKRIS, Jatiwaringin Jakarta Timur \\ Email : Amanda.unkris@setiorini.net
}

\begin{abstract}
This study aims to analyze the effect of competence and work environment on employee performance at PT. Hexindo Adiperkasa Tbk. This is a quantitative descriptive study using primary data by giving questionnaires to employees of PT. Hexindo Adiperkasa Tbk, located in the Pulo Gadung Industrial Estate, Jakarta, discussed on Jl. Goat Island II Kav.I-II.No.33. From a population of 1,500 employees, a total sample of 94 respondents was obtained using the Slovin formula. The technique used to take samples is the random sampling method and the type of data used is heterogeneous. The analytical tool used in this study is multiple linear regression. The results show there is a positive and significant effect simultaneously between competence and work environment on employee performance. Partially, competence has a significant influence on employee performance, as well as work environment variables.
\end{abstract}

\section{Keywords: Competency, work environment, work performance}

\section{PENDAHULUAN}

Dalam era globalisasi, masalah sumber daya manusia menjadi sorotan maupun tumpuan bagi perusahaan untuk tetap dapat bertahan. Sumber daya manusia mempunyai peran utama dalam setiap kegiatan perusahaan. Walaupun banyaknya sarana dan prasarana serta sumber daya, tanpa dukungan sumber daya manusia kegiatan perusahaan tidak akan berjalan dengan baik. Dengan demikian sumber daya manusia merupakan kunci pokok yang harus diperhatikan dalam segala kebutuhannya. Sumber daya manusia akan menentukan keberhasilan pelaksanaan kegiatan perusahaan. Untuk itu dalam mencapai tujuan ini perusahaan dibutuhkan sumber daya manusia yang berkualitas tinggi sehingga dapat meningkatkan kinerja karyawan.
Karyawan atau pegawai merupakan unsur terpenting dalam menentukan maju dan berkembangnya perusahaan. Untuk mencapai hal tersebut perusahaan perlu memiliki karyawan yang sesuai persyaratan yang dibutuhkan oleh perusahaan. Setiap perusahaan akan selalu meningkatkan kinerja karyawannya dengan harapan agar tujuan perusahaan tercapai. Kemampuan karyawan menjadi kunci utama dalam menjalankan kesuksesan perusahaan. Dengan dimilikinya kinerja karyawan yang optimal, maka hal tersebut telah menjadi modal bagi perusahaan dalam mencapai tujuannya. Sehingga kinerja karyawan adalah hal yang patut diperhatikan oleh perusahaan.

Penelitian kali ini dilakukan pada PT Hexindo Adiperkasa Tbk, untuk selanjutnya disebut Hexindo atau Perseroan merupakan perusahaan yang fokus pada perdagangan, penyewaan alat 
berat, remanufaktur dan penyediaan layanan purna jual sebagai perusahaan yang telah memiliki Visi dan Misi yang menjadi landasan bagi perusahaan untuk menetapkan strategi-strategi bisnis yang akan dijalankan dalam memenangkan persaingan. Adapun Visi PT Hexindo Adiperkasa Tbk adalah menjadi perusahaan kelas dunia dalam industri alat-alat berat di Indonesia dengan kualitas pelayanan terbaik bagi semua pihak yang berkepentingan, sedangkan Misi nya adalah menciptakan meningkatkan kualitas kerja para karyawan yang berkesinambungan dalam lingkungan kerja yang semakin kondusif, sekaligus membantu mereka mencapai kesejahteraan.

Sumber daya yang ada dalam organisasi seperti PT Hexindo Adiperkasa akan mempengaruhi berhasilnya suatu organisasi untuk kelangsungan hidup organisasi, baik sumber daya manusia maupun modal. Oleh karna itu perusahaan harus menjalankan fungsinya dengan baik, salah satunya dengan meningkatkan kinerja karyawanya, peningkatkan kinerja karyawan memiliki dua cara yaitu terdapat pada kompetensi dan lingkungan kerja yang baik.

Sebagaimana yang telah di kemukakan oleh Mangkunegara (2015) kinerja adalah "hasil kerja secara kualitas dan kuantitas yang dicapai oleh seseorang pegawai dalam melaksanakan tugasnya sesuai dengan tanggung jawab yang diberikan kepadanya". Namun kondisi kinerja karyawan belakangan ini pada PT. Hexindo Adiperkasa mengalami penurunan. Dimana permasalahan tersebut berpengaruh pada kualitas dan kuantitas karyawan. Karena kualitas dan kuantitas yang meningkat memberikan pencapaian target yang dibutuhkan perusahaan, maka dari itu pemimpin perusahaan harus lebih memberikan perhatiannya pada karyawan untuk mengetahui peningkatan kinerja karyawannya agar dapat bekerja secara efektif guna mencapai kesuksesan perusahaan.

Berikut dapat dilihat data kuantitas pekerjaan karyawan selama tiga tahun terakhir 2016-2018.

\begin{tabular}{cccc} 
Tabel 1: Target Kerja Karyawan PT. Hexindo Adiperkasa tahun & 2016-2018 \\
\hline Tahun & Target Tahunan & Realisasi & Presentase \\
\hline 2016 & 2.060 & 1.471 & $71,41 \%$ \\
2017 & 2.500 & 1.342 & $53,68 \%$ \\
2018 & 1,950 & 9.55 & $48.97 \%$ \\
\hline
\end{tabular}

Sumber PT. Hexindo Adiperkasa Tbk 2019

Faktor lain yang juga berpengaruh dalam penilaian kinerja karyawan yaitu adalah kompetensi. Kompetensi merupakan karakteristik dari seseorang yang dapat diperlihatkan, yang meliputi pengetahuan, keterampilan, dan perilaku, yang dapat menghasilkan kinerja dan prestasi Dessler (2006). Dalam hal ini kompetensi karyawan PT. Hexindo Adiperkasa memiliki permasalahan yaitu, pengetahuan dalam melaksanakan tugas. Dimana keterbatasan pengetahuan karyawan akan tugas yang diberikan perusahan kurang dapat dipahami dengan baik dan memiliki dampak keterlambatan pada tugas yang diberikan. Dengan ini perusahaan harus memberi perhatian, dengan memberikan pelatihan kerja yang sesuai pekerjaan kepada karyawan, demi berkembangnya kemampuan dan pengalaman yang dimiliki karyawan serta guna tercapainya hasil yang sempurna bagi PT. Hexindo Adiperkasa. Dapat disimpulkan bahwa kompetensi yang 
kurang berkembang pada karyawan PT. Hexindo Adiperkasa terjadi karena pengetahuan dalam melaksanakan tugas tidak cukup baik.

Disamping itu bukan hanya kompetensi yang dapat meningkatkan kinerja karyawan namun lingkungan kerja yang baik atau kondusif juga dapat meningkatkan kinerja karyawan itu sendiri. Menurut Nitisemito (2010) lingkungan kerja adalah "bahwa segala sesuatu yang ada disekitar para pekerja yang dapat mempengaruhi dirinya dalam menjalankan tugas-tugas yang dibebankan". Pada saat ini kondisi lingkungan kerja PT. Hexindo Adiperkasa memiliki permasalahan yang dikatakan kurang nyaman karena suhu udara di ruang kerja PT. Hexindo Adiperkasa tidak tetap dan berubah ubah. Ruang kerja tersebut menjadi hambatan pada lingkungan kerja perusahaan dan membuat rasa nyaman terganggu dan membuat kinerja karyawan menurun. Dengan demikian untuk memaksimalkan kinerja karyawan perusahaan penting dalam memperhatikan bahwa karyawan harus bekerja di suatu lingkungan dimana suhu diatur dengan baik dan sejuk. Oleh karena itu untuk meningkatkan PT. Hexindo Adiperkasa harus dapat memenuhi kebutuhan lingkungan kerja perusahaan, demi meningkatkan kinerja karyawan.

Tujuan penelitian ini adalah untuk mengetahui pengaruh kompetensi dan lingkungan kerja terhadap kinerja karyawan PT. Hexindo Adiperkasa.

\section{LANDASAN TEORI}

\section{Kompetensi}

Kompetensi adalah suatu hal yang dikaitkan dengan kemampuan, pengetahuan atau wawasan, dan sikap yang dijadikan suatu pedoman dalam melakukan tanggung jawab pekerjaan yang dikerjakan oleh pegawai.
Kesuksesan yang didapat pegawai adalah hasil dari peningkatan kompetensi pegawai selama bekerja di perusahaan. Menurut Wibowo (2016) menyebutkan bahwa kompetensi adalah "Suatu kemampuan untuk melaksanakan atau melakukan suatu pekerjaan atau tugas yang dilandasi atas keterampilan dan pengetahuan serta didukung oleh sikap kerja yang dituntut oleh pekerjaan tersebut". Lebih lanjut Menurut Sudarmanto (2009) mendefinisikan "Kompetensi sebagai pengetahuan keahlian, kemampuan, atau karakteristik pribadi individu yang mempengaruhi secara langsung kinerja pekerjaan. Kompetensi menggambarkan dasar pengetahuan dan standar kinerja yang dipersyaratkan agar berhasil menyelesaikan suatu pekerjaan atau memegang suatu jabatan. Sedangkan menurut Edison (2016) "Kompetensi adalah kemampuan individu untuk melaksanakan suatu pekerjaan dengan benar dan memiliki keunggulan yang didasarkan pada hal-hal yang menyangkut pengetahuan, keahlian, dan sikap.

Wibowo (2016) mengungkapkan bahwa terdapat beberapa faktor yang dapat mempengaruhi kecakapan kompetensi seseorang, yang dapat berpengaruh dalam pekerjaannya, dan akan dijelaskan sebagai berikut : 1). "Keyakinan dan nilai-nilai; Keyakinan orang tentang dirinya maupun terhadap orang lain akan sangat mempengaruhi perilaku. Apabila orang lain percaya bahwa mereka tidak kreatif dan inovatif. Maka mereka tidak akan berusaha berfikir tentang cara baru atau berbeda dalam melakukan sesuatu. Kepercayaan banyak pekerja bahwa manajemen merupakan musuh yang akan mencegah mereka melakukan inisiatif yang seharusnya dilakukan. Demikian pula apabila manajer merasa bahwa mereka hanya mempunyai sedikit pengaruh, merek tidak meningkatkan 
usaha dan energi untuk mengidentifikasi tentang bagaimana mereka harus memperbaiki sesuatu. Untuk itu, setiap orang harus berfikir positif baik tentang dirinya maupun terhadap orang lain dan menunjukan ciri orang yang berfikir kedepan. 2). Keterampilan; Keterampilan memainkan peran dikebanyakan kompetensi. Berbicara di depan umum merupakan keterampilan yang dapat dipelajari, dipraktikan dan diperbaiki. Keterampilan menulis juga dapat diperbaiki dengan instruksi, praktik dan umpan balik. Dengan memperbaiki keterampilan berbicara didepan umum dan menulis. Individu akan meningkat kecakapannya dalam kompetensi tentang perhatian terhadap komunikasi. Keterampilan sangat dibutuhkan untuk menunjang pekerjaan yang akan dikerjakan agar lebih baik lagi. Pengembangan keterampilan yang secara spesifik berkaitan dengan kompetensi dapat berdampak baik pada budaya organisasi dan kompetensi individual. Sehungga dapat memudahkan mereka dalam menyelesaikan tugas yang diberikan oleh atasan dengan baik dan benar. 3). Karakteristik Kepribadian; Dalam kepribadian termasuk banyak faktor yang diantaranya sulit untuk berubah. Akan tetapi, kepribadian bukanlah sesuatu yang tidak dapat berubah. Kentaannya, kepribadian seseorang dapat berubah sepanjang waktu. Orang merespon dan berinteraksi dengan kekuatan dan lingkungan sekitarnya. Kepribadian dapat mempengaruhi keahlian manajer dan pekerja dalam sejumlah kompetensi, termasuk dalam menyeslesaikan konflik, menunjukan kepedulian interpersonal, kemampuan bekerja dalam tim, memberikan pengaruh dan membangun hubungan. 4). Isu emosional; Hambatan emosional dapat membatasi penguasaan kompetensi. Takut membuat kesalahan, menjadi malu, merasa tidak disukai atau tidak menjadi bagian, semuanya cenderung membatasi motivasi dan inisiatif. Perasaan tentang kewenangan dapat mempengaruhi kemampuan omunikasi dan menyelesaikan konflik dengan manajer. Mengatasi pengalaman yang tidak menyenangkan akan memperbaiki penguasaan dalam banyak kompetensi. 5). Kemampuan intelektual; Kompetensi tergantung pada pemikiran kognitif seperti pemikiran konseptual dan pemikiran analitis, faktor pengalaman dapat meningkatkan kecakapan dalam berorganisasi. 6). Budaya organisasi; Budaya organisasi mempengaruhi kompetensi sumber daya manusia dalam kegiatan sebagai berikut: a). Praktik rekriutment dan seleksi karyawan, untuk mempertimbangkan siapa diantara pekerja yang dimasukan dalam organisasi dan tingkat keahliannya tentang kompetensi. b). Sistem penghargaan mengkomunikasikan pada pekerja bagaimana organisasi menghargai kompetensi. c). Praktik pengambilan keputusan mempengaruhi kompetensi dalam memberdayakan orang lain, inisiatif dan memotivasi orang lain".

Adanya manfaat kompetensi menurut Prihadi (2004) adalah: 1). "Prediktor kesuksesan kerja: Model kompetensi yang akurat akan dapat menentukan dengan tepat pengetahuan serta keterampilan apa saja yang dibutuhkan untuk berhasil dalam suatu pekerjaan. Jika seseorang yang memiliki posisi dapat memiliki kompetensi yang dijadikan syarat pada posisinya maka dia dapat diprediksikan akan sukses. 2). Merekrut karyawan yang andal: Apabila telah berhasil ditentukan kompetensi apa saja yang diperlukan suatu posisi tertentu, maka dengan mudah untuk menjadi kriteria dasar dalam rekruitmen karyawan baru. 3). Menjadi dasar dalam penilaian dan pengembangan karyawan: Identifikasi kompetensi pekerjaan yang akurat dapat digunakan sebagai tolak ukur kemampuan seseorang". Berdasarkan sistem 
kompetensi ini dapat diketahui apakah seseorang telah mengembangkannya, dengan pelatihan dan pembinaan atau perlu dimutasikan kebagian lain.

Menurut Wibowo (2016) indikator kompetensi adalah sebagai berikut: 1). "Pengetahuan adalah informasi yang telah diproses dan diorganisasikan untuk memperoleh pemahaman, pembelajaran, dan pengalaman yang terakumulasi sehingga bisa diaplikasikan untuk melaksanakan tugas dan tanggung jawabnya sesuai bidang tertentu yang digelutinya. Pengetahuan karyawan turut menentukan berhasil tidaknya pelaksanaan tugas yang dibebankan kepadanya. Karyawan yang mempunyai pengetahuan yang cukup akan meningkatkan efisiensi perusahaan. 2). Keterampilan merupakan kemampuan seseorang untuk menggunakan akal, pikiran, dan kreativitasnya dalam mengerjakan, mengubah, menyelesaikan ataupun membuat sesuatu menjadi lebih bermakna sehngga menghasilkan sebuah nilai dari hasil pekerjaan tersebut. 3). Sikap kerja merupakan pola kecenderungan tingkah laku dalam merespon sesuatu secara konsisten untuk mendukung atau tidak mendukung tugas dan tanggung jawabnya sesuai dengan peraturan perusahaan. Apabila karyawanmempunyai sifat mendukung pencapaian organisasi, maka secara otomatis segala tugas yang dibebankan kepadanya akan dilaksanakan sebaikbaiknya".

\section{Lingkungan Kerja}

Menurut Sedamaryanti (2011) adalah "Keseluruhan alat perkakas dan bahan yang dihadapi, lingkungan sekitarnya dimana seseorang bekerja, metode kerjanya, serta pengaturan kerjanya baik sebagai perseorangan maupun sebagai kelompok". Sunyoto (2015) "Lingkungan kerja merupakan komponen yang sangat penting ketika karyawan melakukan aktivitas bekerja.
Dengan memperhatikan lingkungan kerja yang baik atau menciptakan kondisi kerja yang mampu memberikan motivasi untuk bekerja, maka akan membawa pengaruh terhadap kinerja karyawan dalam bekerja". Selanjutnya menurut Widodo (2015) "Lingkungan kerja merupakan lingkungan dimana para karyawan dapat melaksanakan tugasnya sehari-hari dengan keseluruhan sarana dan prasarana kerja yang diperlukan untuk melaksanakan tugas-tugas tersebut".

Lingkungan kerja didalam perusahaan/instansi sangat penting diperhatikan oleh pimpinan karena lingkungan kerja yang baik mempunyai pengaruh terhadap efektivitas yang bekerja dalam perusahaan. Di dalam usaha untuk membuatperencanaan lingkungan kerja maka perlu mengkaji dan menentukan aspek-aspek pembentuk lingkungan kerja itu sendiri. Menurut Siagian (2014) menyatakan bahwa secara garis besar, lingkungan kerja terdapat dua jenis yaitu : 1). "Lingkungan kerja fisik adalah semua keadaan berbentuk fisik yang terdapat disekitar tempat kerja dan dapat mempengaruhi karyawan. Ada beberapa kondisi fisik dari tempat kerja yang baik yaitu : a). Bangunan tempat kerja disamping menarik untuk dipandang juga dibangun dengan pertimbangan keselamatan kerja. b). Tersedianya peralatan kerja yang memadai. c). Tersedianya tempat istirahat untuk melepas lelah, seperti kafetaria baik dalam lingkungan perusahaan atau sekitarnya yang mudah dicapai karyawan. d). Tersedianya tempat ibadah keagamaan seperti masjid dan musholla untuk karyawan. e). Tersedianya sarana angkutan, baik yang diperuntukkan karyawan maupun angkutan umum yang nyaman, murah dan mudah di peroleh. 2). Lingkungan kerja non fisik adalah lingkungan kerja yang menyenangkan dalam arti terciptanya hubungan kerja yang harmonis antara karyawan dan atasan, karena pada hakekatnya manusia 
dalam bekerja tidak hanya mencari uang saja, akan tetapi bekerja merupakan bentuk aktivitas yang bertujuan untuk mendapatkan kepuasan. Dari beberapa pendapat diatas dapat disimpulkan bahwa lingkungan kerja fisik merupakan keadaan berbentuk fisik yang mencakup setiap hal dari fasilitas organisasi yang dapat memepengaruhi karyawan dalam melaksanakan pekerjaan atau efektivitas. Sedangkan lingkungan kerja non fisik merupakan keadaan disekitar tempat kerja yang bersifat non fisik. Lingkungan kerja non fisik tidak dapat di tangkap oleh panca indera manusia, namun dapat dirasakan oleh perasaan misalnya, hubungan antara karyawan dengan pimpinan".

Lingkungan kerja yang baik dapat memicu produktifitas dan kepuasan kerja karyawan. Siagian (2014), mengemukakan bahwa manfaat lingkungan kerja adalah "menciptakan gairah kerja, sehingga produktivitas dan prestasi kerja meningkat, selain itu lingkungan kerja juga dapat berpengaruh terhadap kepuasan kerja karyawan. Kepuasan kerja muncul sebagai akibat dari situasi kerja yang ada di dalam perusahaan. Kepuasan kerja tersebut mencerminkan perasaan karyawan mengenai senang atau tidak senang, nyaman atau tidak nyaman atas lingkungan kerja perusahaan dimana dia bekerja".

Yang menjadi indikator-indikator lingkungan kerja menurut Sedarmayanti (2011) adalah sebagai berikut : 1). "Penerangan atau cahaya sangat besar manfaatnya bagi karyawan guna mendapat keselamatan dan kelancaran kerja. Oleh sebab itu perlu diperhatikan adanya penerangan (cahaya) yang terang tetapi tidak menyilaukan. Cahaya yang kurang jelas, sehingga pekerjaan akan lambat, banyak mengalami kesalahan, dan pada akhirnya menyebabkan kurang efisien dalam melaksanakan pekerjaan, sehingga tujuan organisasi sulit dicapai.
2). Suhu udara adalah suatu variabel dimana terdapat perbedaan individual yang besar. Dengan demikian untuk memaksimalkan produktivitas, adalah penting bahwa pegawai bekerja di suatu lingkungan dimana suhu diatur sedemikian rupa sehingga berada diantara rentang kerja yang dapat diterima setiap individu. 3). Suara bising; Bukti dari telaah-telaah tentang suara menunjukkan bahwa suara-suara yang konstan atau dapat diramalkan pada umumnya tidak menyebabkan penurunan prestasi kerja sebaliknya efek dari suara-suara yang tidak dapat diramalkan memberikan pengaruh negatif dan mengganggu konsentrasi pegawai. 4). Penggunaan Warna; Menata warna di tempat kerja perlu dipelajari dan direncanakan dengan sebaik-baiknya. Pada kenyataannya tata warna tidak dapat dipisahkan dengan penataan dekorasi. Hal ini dapat dimaklumi karena warna mempunyai pengaruh besar terhadap perasaan. Sifat dan pengaruh warna kadang-kadang menimbulkan rasa senang, sedih, dan lain-lain, karena dalam sifat warna dapat merangsang perasaan manusia. 5). Ruang gerak yang di perlukan yang ditimbulkan oleh alat mekanis, yang sebagian dari getaran ini sampai ke tubuh karyawan dan dapat menimbulkan akibat yang tidak diinginkan. 6). Keamanan kerja; Guna menjaga tempat dan kondisi lingkungan kerja tetap dalam keadaan aman maka perlu diperhatikan adanya keberadaannya. Salah satu upaya untuk menjaga keamanan di tempat kerja, dapat memanfaatkan tenaga satuan petugas keamanan (Satpam). 7). Hubungan karyawan; Hubungan karyawan merupakan bentuk hubungan dari suatu pribadi ke pribadi yang lain dalam suatu organisasi. Apabila tercipta hubungan yang harmonis dapat menguntungkan pihak perusahaan karena karyawan dapat mengembangkan diri tanpa terbatasi dengan yang lainya". 


\section{Kinerja Karyawan}

Menurut Rivai (2004) "Kinerja adalah hasil kerja yang dapat dicapai oleh seseorang atau kelompok oang dalam suatu perusahaan sesuai dengan wewenang dan tanggung jawab masingmasing dalam upaya pencapaian tujuan perusahaan secara legal, tidak melanggar hukum dan tidak bertentangan dengan moral atau etika". Menurut Sutrisno (2016) "Kinerja adalah kesuksesan seseorang dalam melaksanakan tugas, hasil kerja yang dapat dicapai oleh seseorang atau sekelompok orang dalam suatu organisasi sesuai dengan wewenang dan tanggung jawab masing-masing atau tentang bagaimana seseorang diharapkan dapat berfungsi dan berperilaku sesuai dengan tugas yang telah dibebankan kepadanya serta kuantitas, kualitas, dan waktu yang digunakan dalam menjalankan tugas, selanjutnya menurut Kasmir (2016:182) mengatakan "Kinerja merupakan hasil kerja dan perilaku kerja yang telah dicapai dalam menyelesaikan tugas-tugas dan tanggung jawab yang diberikan dalam suatu periode tertentu. Meningkatnya kinerja perorangan, maka kemungkinan besar juga akan meningkatkan kinerja perusahaan karena keduanya mempunyai hubungan yang erat.

Tujuan evaluasi kinerja adalah untuk memperbaiki atau meningkatkan kinerja organisasi melalui peningkatan kinerja dari SDM organisasi. Secara lebih spesifik, tujuan evaluasi kinerja sebagaimana dikemukakan Sunyoto dalam Mangkunegara (2015) yaitu: a). Meningkatkan saling pengertian antara karyawan tentang persyaratan kinerja. b). Mencatat dan mengakui hasil kerja seorang karyawan, sehingga mereka termotivasi untuk berbuat yang lebih baik, atau sekurang-kurangnya berprestasi sama dengan prestasi yang terdahulu. c). Memberikan peluang kepada karyawan untuk mendiskusikan keinginan dan aspirasinya dan meningkatkan kepedulian terhadap karier atau terhadap pekerjaan yang diembannya sekarang. d). Mendefinisikan atau merumuskan kembali sasaran masa depan, sehingga karyawan termotivasi untuk berpartisipasi sesuai dengan potensinya. e). Memeriksa rencana pelaksanaan dan pengembangan yang sesuai dengan kebutuhan pelatihan, khusus rencana dikalat, dan kemudian menyutujui rencana itu jika tidak ada halhal yang perlu diubah.

Kegunaan penilaian kinerja karyawan yaitu: a). Sebagai dasar dalam pengambilan keputusan yang digunakan untuk prestasi, pemberhentian dan besarnya balas jasa. b). Untuk mengukur sejauh mana seorang karyawan dapat menyelesaikan pekerjaannya. c). Sebagai dasar untuk mengevaluasi efektivitas seluruh kegiatan dalam perusahaan. d). Sebagai dasar untuk mengevaluasi program latihan dan keefektifan jadwal kerja, metode kerja, struktur organisasi, gaya pengawasan, kondisi kerja dan pengawasan. e). Sebagai indikator untuk menentukan kebutuhan akan latihan bagi karyawan yang berada di dalam organisasi. f). Sebagai alat untuk meningkatkan motivasi kerja karyawan sehingga dicapai performance yang baik. g). Sebagai alat untuk melihat kekurangan atau kelemahan dan meningkatkan kemampuan karyawan selanjutnya. h). Sebagai kriteria menentukan, seleksi dan penempatan karyawan. i). Sebagai alat untuk memperbaiki atau mengembangkan kecakapan karyawan. j). Sebagai dasar untuk memperbaiki atau mengembangkan uraian tugas.

Menurut Mangkunegara (2015), mengemukakan bahwa indikator kinerja yaitu: a). "Kualitas kerja adalah seberapa baik seorang karyawan mengerjakan apa yang seharusnya dikerjakan. b). Kuantitas kerja adalah seberapa lama seorang pegawai bekerja dalam satu harinya. Kuantitas kerja ini dapat dilihat 
darikecepatan kerja setiap pegawai itu masing-masing. c). Pelaksanaan tugas adalah seberapa jauh karyawan mampu melakukan pekerjaannya dengan akurat atau tidak ada kesalahan. d). Tanggung jawab terhadap pekerjaan adalah kesadaran akan kewajiban karyawan untuk melaksanakan pekerjaan yang diberikan perusahaan".

\section{METODE PENELITIAN}

Penelitian ini untuk menjelaskan hubungan kausalitas variabel kompetensi dan lingkungan kerja terhadap kinerja karyawan. Data yang digunakan dalam penelitian ini merupakan data primer melalui pengisian kuesioner kepada para karyawan. Metode analisis yang digunakan adalah metode analisis regresi linear sederhana dan berganda. Populasi dalam penelitian ini adalah karyawan PT. Hexindo Adiperkasa yang berjumlah 1500 orang.

Dasar pengambilan jumlah sampel digunakan rumus Slovin (Husein, 2011). Berdasarkan perhitungan rumus Slovin tersebut diambil menjadi sampel sebanyak 94 karyawan. teknik pengambilan sampel yang digunakan dalam penelitian ini adalah simple random sampling yaitu peneliti dalam memilih sampel dengan memberikan kesempatan yang sama kepada semua anggota populasi untuk ditetapkan sebagai anggota sampel.

\section{HASIL PENELITIAN DAN PEMBAHASAN}

\section{Uji Instrumen Data}

Berdasarkan uraian tersebut di atas, maka untuk dapat menentukan apakah variabel kompetensi dan lingkungan kerja dapat dijadikan pengukur terhadap kinerja karyawan PT. Hexindo Adiperkasa. Namun sebelumnya data diolah terlebih dahulu dan dilakukan pengujian terhadap varibel yang digunakan yaitu kompetensi dan lingkunan kerja untuk mengetahui apakah data tersebut akurat dan dapat dipercaya.

\section{Uji Validitas}

Pengujian validitas ini dilakukan untuk menguji apakah tiap butir pernyataan telah mewakili indikator yang akan diteliti, persyaratan minimum untuk dapat dikatakan valid adalah $r=0,30$. Jadi, apabila korelasi antara butir-butir item pernyataan dengan skor total kurang dari 0,30, maka butiran dalam instrumen tersebut dapat dikatakan tidak valid. Uji validitas dilakukan dengan melihat korelasi antara skor masing-masing item pernyataan dengan skor total.

\section{Uji Validitas Instrumen Variabel}

Dari perhitungan koefisien korelasi skor tiap butir pernyataan dari 94 responden tentang instrument kompetensi dengan jumlah 6 pernyataan; instrumen lingkungan kerja 13 pernyataan dan instrumen kinerja karyawan 9 pernyataan menunjukkan $\mathrm{r}$ hitung $>\mathrm{r}$ kritis $=0.3$, hasilnya adalah valid.

\section{Uji Reliabilitas}

Pengujian reliabilitas ini dilakukan untuk menguji seberapa jauh hasil pengukuran yang dapat diandalkan secara konsisten. Pada tabel hasil pengujian reliabilitas berikut, diketahui bahwa semua variabel mempunyai alpha di atas 0,6 yang berarti bahwa semua variabel dalam penelitian ini dapat diandalkan. 
Tabel 2 : Hasil Uji Reliabilitas Variabel

\begin{tabular}{lcc}
\hline Variabel & Cronbach's Alpha & Keterangan \\
\hline Kompetensi & 0.631 & Reliabel \\
Lingkungan Kerja & 0.620 & Reliabel \\
Kinerja Karyawan & 0.733 & Reliabel \\
\hline
\end{tabular}

Sumber: Hasil pengolahan data, 2019

Berdasarkan Tabel 2, dapat dilihat dan disimpulkan bahwa nilai Cronbach's Alpha positif dimana lebih besar dari 0,6 yang merupakan batas minimal koefisien reliabilitas dapat dianggap baik.

\section{Analisis Hasil Penelitian}

Tabel 3: Pengaruh Kompetensi dan Lingkungan Kerja Terhadap Kinerja Karyawan PT. Hexindo Adiperkasa

\begin{tabular}{lrcrrrr}
\hline \multirow{2}{*}{ Variabel } & \multicolumn{6}{c}{ Parameter } \\
\cline { 2 - 7 } & Mult. R & R Square & Konstanta & \multicolumn{1}{c}{ Koef. B } & \multicolumn{1}{c}{ Sig. } & \multicolumn{1}{c}{$\boldsymbol{\alpha}$} \\
\hline Kompetensi & \multirow{2}{*}{0.832} & \multirow{2}{*}{0.693} & 2.746 & $\begin{array}{l}0.822 \\
0.299\end{array}$ & 0.000 & \multirow{2}{*}{0.05} \\
Lingkungan Kerja & & & & & &
\end{tabular}

\section{Pengujian Signifikansi}

F hitung $>$ F tabel $=102.727>3.097$

Keterangan : Variabel Kinerja Karyawan Sumber: data diolah 2019

Berdasarkan Tabel 3, nilai $\mathrm{F}$ hitung sebesar 102,727 lebih besar dibandingkan dengan $\mathrm{F}$ tabel 3,097, artinya secara bersama-sama kompetensi dan lingkungan kerja berpengaruh signifkan terhadap kinerja karyawan PT. Hexindo Adiperkasa. Nilai R square sebesar 0,693 atau 69,3\%. Hal ini berarti bahwa kompetensi dan lingkungan kerja memberikan kontribusi kepada kinerja karyawan PT. Hexindo Adiperkasa adalah sebesar $69,3 \%$, sedangkan sisanya sebesar 30,7\% disumbangkan oleh variabel lainnya yang tidak diteliti.

\begin{abstract}
Berdasarkan hasil perhitungan koefisien regresi secara simultan diperoleh persamaan regresi yaitu sebesar $\mathrm{Y}=2,746+0,822\left(\mathrm{X}_{1}\right)+0,299\left(\mathrm{X}_{2}\right)$. Koefisien kompetensi bertanda positif, hal ini berarti bahwa setiap penambahan kompetensi, maka kinerja karyawan PT. Hexindo Adiperkasa akan meningkat, dengan asumsi lingkungan kerja tetap. Koefisien lingkungan kerja bertanda positif, hal ini berarti bahwa setiap peningkatan lingkungan kerja, maka kinerja karyawan PT. Hexindo Adiperkasa akan meningkat, dengan asumsi kompetensi tetap.
\end{abstract}

Tabel 4: Pengaruh Kompetensi Terhadap Kinerja Karyawan PT. Hexindo Adiperkasa

\begin{tabular}{lcccccc}
\hline \multirow{2}{*}{ Variabel } & $\mathbf{R}$ & R Square & Konstanta & Koef. B & Sig. & $\boldsymbol{\alpha}$ \\
\cline { 2 - 7 } & 0.799 & 0.638 & 10.846 & 1.115 & 0.000 & 0.05 \\
\hline Kompetensi & \multicolumn{7}{c}{ Parameter } \\
\hline Pengujian Signifikansi & & & & & \\
\hline t hitung $>$ t tabel $=12.759$ & $>1.986$
\end{tabular}

Keterangan : Variabel Kinerja Karyawan

Sumber: data diolah 2019 
Berdasarkan Tabel 4, nilai koefisien determinasi ( $\mathrm{R}$ square) sebesar 0,638 atau $63,8 \%$, hal ini berarti bahwa kompetensi memberikan kontribusi kepada kinerja karyawan PT. Hexindo Adiperkasa adalah sebesar 63,8\%, sedangkan sisanya sebesar $36,2 \%$ disumbangkan oleh variabel lainnya yang tidak diteliti, seperti lingkungan kerja. Persamaan regresi yaitu sebesar $\mathrm{Y}=$ $10,846+1,115\left(\mathrm{X}_{1}\right) . \quad$ Koefisien kompetensi bertanda positif, hal ini berarti bahwa setiap peningkatan kompetensi, maka kinerja karyawan PT. Hexindo Adiperkasa akan meningkat.

Nilai t hitung sebesar 12,759 lebih besar dibandingkan dengan t tabel 1,986, maka dapat diartikan bahwa pengaruh kompetensi berpengaruh signifikan terhadap kinerja karyawan PT. Hexindo Adiperkasa.

Tabel 5: Pengaruh Lingkungan Kerja Terhadap Kinerja Karyawan PT. Hexindo Adiperkasa

\begin{tabular}{lcccccc}
\hline \multirow{2}{*}{ Variabel } & $\mathbf{R}$ & R Square & Konstanta & Koef. B & Sig. & $\boldsymbol{\alpha}$ \\
\cline { 2 - 6 } & 0.670 & 0.449 & 3.619 & 0.676 & 0.000 & 0.5 \\
\hline $\begin{array}{l}\text { Lingkungan } \\
\text { Kerja }\end{array}$ & & & & & & \\
\hline Pengurany
\end{tabular}

Pengujian Signifikansi

$\mathrm{t}$ hitung $>\mathrm{t}$ tabel $=9.618>1.986$

Keterangan : Variabel Kinerja Karyawan

Sumber: data diolah 2019

Berdasarkan Tabel 5, nilai koefisien determinasi ( $\mathrm{R}$ square) sebesar 0,449 atau $44,9 \%$, hal ini berarti bahwa lingkungan kerja memberikan kontribusi kepada kinerja karyawan PT. Hexindo Adiperkasa adalah sebesar 44,9\%, sedangkan sisanya sebesar $55,1 \%$ disumbangkan oleh variabel lainnya yang tidak diteliti, seperti kompetensi. Persamaan regresi yaitu sebesar $\mathrm{Y}=$ $3,619+0,676\left(X_{1}\right)$. Koefisien lingkungan kerja bertanda positif, hal ini berarti bahwa setiap peningkatan lingkungan kerja, maka kinerja karyawan PT. Hexindo Adiperkasa akan meningkat.

Nilai t hitung sebesar 9,618 lebih besar dibandingkan dengan t tabel 1,986, maka dapat diartikan lingkungan kerja berpngaruh signifikan terhadap kinerja karyawan PT. Hexindo Adiperkasa.

\section{Pembahasan}

\section{Pengaruh Kompetensi dan Lingkungan Kerja Terhadap Kinerja Karyawan}

Berdasarkan hasil penelitian diketahui bahwa kompetensi dan lingkungan kerja dapat mendorong peningkatan kinerja karyawan. Hal ini sejalan dengan penelitian terdahulu yang dilakukan Efendi, et al, yang menunjukkan bahwa kompetensi berpengaruh signifikan terhadap kinerja karyawan PR Adi Bungsu Malang, lingkungan kerja berpengaruh signifikan terhadap kinerja karyawan PR. Adi Bungsu Malang, kompetensi dan lingkungan kerja secara bersama-sama berpengaruh terhadap kinerja karyawan PR. Adi Bungsu Malang. 


\section{Pengaruh Kompetensi Terhadap Kinerja Karyawan}

Kompetensi

mendukung

peningkatan terhadap kinerja karyawan.

Hal ini menunjukkan bahwa semakin baik kompensasi yang diberikan oleh perusahaan maka akan dapat meningkaktan kinerja karyawan. Hasil penelitian ini juga sejalan dengan penelitian terdahulu yang dilakukan oleh Mubarok dan Putra (2018) yang menunjukkan bahwa Pertama, pelatihan, kompetensi, dan motivasi secara bersama-sama berpengaruh signifikan terhadap kinerja karyawan. Kedua, kompetensi yang menunjukkan peningkatan kinerja karyawan yang signifikan. Ketiga, pelatihan secara signifikan mempengaruhi kinerja karyawan. Keempat, sama saja, motivasi berprestasi akan memiliki pengaruh yang signifikan terhadap kinerja karyawan. Kelima, berdasarkan koefisien, kompetensi menunjukkan, lebih besar pada kinerja karyawan pada variabel motivasi untuk prestasi dan pelatihan. Oleh karena itu, penelitian dapat dipertimbangkan sebagai dasar dalam mengelola perusahaan.

\section{Pengaruh Lingkungan Kerja Terhadap Kinerja Karyawan}

Lingkungan kerja mendukung peningkatan kinerja karyawan, berarti bahwa semakin baik lingkungan kerja yang ada dalam pearusahaan akan dapat meningkatkan kinerja karyawan. Hal ini sejalan dengan penelitian terdahulu yang dilakukan oleh Muchtar (2016) yang menunjukkan bahwa motivasi kerja tidak berpengaruh terhadap kinerja karyawan, sedangkan, Lingkungan kerja berpengaruh signifikan terhadap kinerja karyawan.

\section{KESIMPULAN DAN SARAN}

\section{Kesimpulan}

Berdasarkan hasil penelitian dan pembahasan mengenai pengaruh kompetensi dan lingkungan kerja terhadap kinerja karyawan, maka intisari dari hasil penelitian tersebut dapat ditarik kesimpulan sebagai berikut : 1). Kompetensi dan lingkungan kerja mendukung peningkatan kinerja karyawan. 2). Kompetensi mendukung peningkatan kinerja karyawan. 3). Lingkungan kerja mendukung peningkatan kinerja karyawan. 4). Kompetensi lebih besar dibandingkan lingkungan kerja dalam mendukung kinerja karyawan, hal ini menunjukkan bahwa kompetensi merupakan faktor yang menentukan untuk peningkatan kinerja karyawan dibandingkan dengan lingkungan kerja.

\section{Saran}

Berdasarkan kesimpulan yang telah dikemukakan diatas, maka peneliti berusaha memberikan saran yang mungkin dapat dijadikan masukan bagi pihak-pihak terkait atau pihak yang berkepentingan agar dapat dipertimbangkan, saran yang dapat peneliti sampaikan, yaitu : 1). Pimpinan Perusahaan PT. Hexindo Adiperkasa sudah memberikan pelatihan pada karyawan, tetapi masih adanya kesalahan pada karyawan tersebut. Agar meningkatkan kompetensi karyawan, supaya pengetahuan dan keterampilan yang dimiliki karyawan dapat meningkat maka atasan memberikan ketegasan lebih pada karyawan atau memberikan sanksi. 2). Pimpinan perusahaan pentingnya meningkatkan suasana lingkungan kerja yang baik dalam membantu kinerja karyawan, terutama dalam hal suhu udara di tempat kerja yang tidak tetap dan berubah-ubah. Maka perlu ditingkatkan kualitas sarana dan prasarana seperti pemasangan $\mathrm{AC}$ yang cukup memadai 
agar dapat menunjang peningkatan kinerja karyawan pada PT. Hexindo Adiperkasa. 3). Untuk penelitian selanjutnya dapat mempertimbangkan kemungkinan penggunaan variabel bebas lainnya yang dapat mempengaruhi kompetensi seperti, motivasi, kompensasi, kepemimpinan, dan faktor lainnya sebagainya. Penelitian selanjutnya disarankan untuk mencari refrensi lain lebih banyak lagi sehingga hasil penelitian tersebut akan semakin lebih baik lagi serta dapat memperoleh ilmu pengetahuan yang baru.

\section{DAFTAR PUSTAKA}

Dessler, Gary. 2006. Manajemen Sumber Daya Manusia, Edisi Kesepuluh. PT Indeks. Jakarta.

Edison, at all. 2016. Manajemen Sumber Daya Manusia. cetakan ke-1. Alfabeta. Bandung.

Efendi, Mohamad. Agus, Widarko\& Achmad, Agus Priyono. 2014. Pengaruh Kompetens Dan Lingkungan Kerja Terhadap Kinerja Karyawan. e - Jurnal Riset Manajemen. Malang.

Kasmir. 2016. Manajemen Sumber Daya Manusia. Teori dan Praktik. PT Raja Grafindo Persada. Jakarta.

Mangkunegara, A.A Anwar Prabu. 2015. Manajemen Sumber daya Manusia. PT Remaja Rosdakarya. Bandung.

Mubarok dan Putra. 2018. The Influence of Training, Competence, and Motivation on Employees Performance of Workers Social Security Agency in Banten Province, Indonesia. Vol.9, No.4. Journal of Economics and Sustainable Development.

Muchtar. 2016. The Influence Of Motivation And Work Environmnnt
On The Performance Of employees. Volume 6, Number 2. Sinergi.

Nitisemito, Alex S. 2010. Manajemen personalia Manajemen Sumber Daya Manusia. Edisi Ketiga. Ghalia Indonesia. Jakarta.

Prihadi, Syaiful F. 2004. Assessment Centre Identifikasi, pengukuran dan Pengembangan Kompetensi. Gramedia Pustaka Utama. Jakarta.

Rivai, Veithzal. 2004. Manajemen Sumber Daya Manusia Untuk Perusahaan. Cetakan Pertama. PT. Raja GrafindoPersada. Jakarta.

Sedarmayanti. 2011. Sumber Daya Manusiadan Produktivitas Kerja. Mandar Maju. Jakarta.

Siagian, Sondang. P. 2014. Manajemen Sumber Daya Manusia. Bumi Aksara. Jakarta.

Sri Widodo, Soedarso. 2015. Sistem Informasi Manajemen. Manggu Media. Bandung

Sudarmanto. 2009. Kinerja dan Pengembangan Kompetensi SDM. Pustaka Pelajar. Yogyakarta.

Sugiyono. 2016. Metode Penelitian Pendidikan Pendekatan Kuantitatif, Kualitatif, dan $R \& D$. Alfabeta. Bandung.

Sunyoto, Danang. 2015. Manajemen dan Pengembangan Sumber Daya Manusia. Cetakan Pertama. CAPS (Center for Academic Publishing Service). Yogyakarta.

Sutrisno, Edy. 2016. Manajemen Sumber Daya Manusia. Cetakan ke-8. Prenada Media Group. Jakarta.

Umar, Husein. 2011. Metode Penelitian Untuk Skripsi dan Tesis Bisnis Edisi 11. PT Raja Grafindo Persada. Jakarta.

Wibowo. 2016. Manajemen Kinerja. Edisi Ketiga, Penerbit Raja Grafindo Persada. Jakarta. 